sciendo Порівняльна професійна педагогіка 8(2)/2018

Comparative Professional Pedagogy 8(2)/2018

DOI: $10.2478 /$ rpp-2018-0032

Postgraduate Student, LILIA BARANOVA

Kyiv State University of Telecommunications Address: 7 Solomenska St., 03680, Kyiv, Ukraine

E-mail: lbaranova@ukr.net

\title{
INTERNATIONAL EDUCATIONAL TRENDS IN CROSS-CULTURAL TRAINING
}

\begin{abstract}
The importance of forming intercultural competences and various aspects of the development of an employee's intellectual activity in today's multicultural society has been stressed. Urgent problems of cross-cultural training of employees, such as the formation of intercultural (cross-cultural) competence of future employees in the process of their professional training, the necessity of compiling a complete list of intercultural competences, determining the levels of requirements for the competences of bachelors and masters, development of cultural intelligence, improvement and the introduction of methods for the development of cultural intelligence have been analyzed. It has been defined that as the most important part of culture, education is intended to ensure the entry of a man into culture through their acquisition of cultural values. The main approaches to the study of cultural diversity in educational systems have been analyzed. The necessity of training specialists with advanced cultural intelligence that will carry out professional activity in the intercultural educational space has been revealed. Four principles, the implementation of which within the framework of corporate culture allows building "the third culture", have been highlighted: unity in diversity; integration; cognitive variety; communicative diversity. Three main competencies that reflect the essence of cross-cultural training have been characterized. They are: awareness of social constructiveness of "cultural differences" and the ability to prevent their influence; skills to identify and evaluate cognitive differences which are hidden behind differences of identities; the ability to find and create a "functional interaction" between cognitive differences of employees, which can contribute to the stability of self-regulating integrative organizational systems.
\end{abstract}

Keywords: culture, intercultural communication, intercultural competence, intercultural learning, cross-cultural training.

\section{INTRODUCTION}

Nowadays, the issue of cross-cultural training of future employees is quite urgent, especially for Ukraine which has a lot of problems related to formation of intercultural (cross-cultural) competence of future employees in the process of their professional training; compiling a complete list of intercultural competences; determination of requirements levels for competences of bachelors and masters; development of cultural intelligence; development and implementation of methods for the development of cultural intelligence.

It is worth mentioning that the issue of cross-cultural training was considered in the speech performed by G. de Groot and K. C. Roettgers, who in their report presented the notion of a global organization, under which they understood a company with active participation in the international arena and that is not limited to its cultural, national or state affiliation. They emphasize that the company's globalization does not in any case destroy 
its cultural essence citing G. Hofstede who said: "No man that belongs to some culture can think globally" (Andreeva, 2009). Nevertheless, in reality there arises a necessity to build up a balance between global and local. G. de Grotte and C. Rettgers show that a successful global organization should be culturally competent, and if a sufficient level of cultural competence allows simply counteracting with new challenges of cross-cultural problems, then the high level allows the use of cross-cultural differences as resource for successful cooperation that goes beyond national borders and requires effective integration. For this to happen the following conditions are essential:

1) proper understanding of the differences between national cultures and the consequences of these differences for effective management;

2) appropriate organizational culture that will act either as a stimulating or suppressing factor, affecting many work aspects, such as open communication, support provided by managers to their direct subordinates, and the extent to which employees from other cultures will be included or excluded from the process;

3 ) the right policy that will encourage employees to work successfully with people, which are considerably different from themselves (Casmir, 1999).

\section{THE AIM OF THE STUDY}

The purpose of the article is to analyze current educational issues of cross-cultural training for future employees in the world educational space.

\section{THEORETICAL FRAMEWORK AND RESEARCH METHODS}

History of this professional field of research is quite new - the first considerable publications on the issue of intercultural communication date back no more than 50 years ago. Among the authors of those publications and research work are M. Barker, F. Casmir, S. Egege, R. Hibbins, T. Hunt, B. Leask, R. Macdonald, K. Matoba, P Woods and others. In spite of the "young" age, there are generally recognized organizations with international authority in this scientific and practical space. One of them is the Society for Intercultural Education, Training and Research (SIETAR), which is the largest in the world organization of interdisciplinary orientation, designed for professionals and for those who are still learning to work in the field of intercultural communication. Founded in 1974 in the USA as a consequence of association of specialists working in Peace Corps this organization currently consists of regional offices and unites them into a global organization - SIETAR Global. Today there are divisions of the Society in Europe, Austria, Albatra (Canada), British Colombia (Canada), Middle East, Bulgaria, United Kingdom, Germany, Spain, Netherlands, India, Spain, Poland, USA, France, Japan, as well as a special unit - Youth SIETAR. In Armenia, Brazil, Greece, Ireland, Morocco, Pakistan, Portugal, Taiwan, Singapore, and also in Latin America there exist initiative groups of the Society.

For the purpose of this research, a range of general scientific methods (including study and analysis of reference, scientific, educational print and on-line sources, statistics) as well as comparative, systematization and generalization methods were applied.

\section{RESULTS}

One example of the implementation of modern trends in a particular field of intercultural communication can serve as a model for building a "third culture" and is being actively implemented in the practice of cross cultural management. The presentation of $\mathrm{K}$. Matoba, director of the center for management of cultural diversity at the University of Witten (Germany), on "Management of cognitive differences for the construction of "third culture", presented cognitivist version of this model. His main idea may be illustrated by 
sciendo Порівняльна професійна педагогіка 8(2)/2018

Comparative Professional Pedagogy 8(2)/2018

the following statement: "It is necessary to move beyond such categories as race, gender and others, to individual "invisible" cognitive diversity" (Matoba, 2003).

In general, this model implies that participants in the process of intercultural communication must and can build a third culture through joint negotiations on their cultural differences. This is a process in which all employees of the organization can bring their own cognitive schemes in any situation of inner organizational cooperation through dialogue. The author highlights four principles, the implementation of which within the framework of corporate culture allows you to build "the third culture":

1) unity in diversity;

2) integration;

3) cognitive variety;

4) communicative diversity (Page, 2007).

We consider it necessary to describe each of them in detail.

The first principle of "unity in diversity" is related to how the organization manages the cultural diversity of its employees. K. Matoba suggests using the scheme of correlation of individual and group in the organization. In his opinion, it is possible to distinguish six traditional ways of such a relationship, which lie in the space of the continuum between monotony and fragmentation (Matoba, 2003).

Each of these approaches has its own characteristics. So, fragmentation is based on the values of personal autonomy and individual freedom of every employee, independent achievement of one's own goals and providing a good state of feeling.

The functional approach is related to the notion that the boundaries of the emerging group within organizations depend on the community, interests, attribution and flexibility. The formation of a group and the choice of its members are random and there is no place to "group loyalty" (Pelled, Pelled, Eisenhardt, \& Xin, 1999).

According to the moral-individualistic approach, a group is determined as a carrier of rational (that is, due to a specific necessity) principles, rules and norms which promote communication of independent individuals.

The "coexistence" approach denotes the possibility of various elements (individual and cultural) to coexist within social institutions of the organization. An important moment here is the division between "personal" (intimate) and "public" (external).

The model of subordination or "comfort" is associated with the necessity to unify thoughts, ideas and emotions of the group members. It is worth mentioning that in the process of this great efforts are made to achieve "connectivity" of the group (Barker, Hibbins, \& Woods, 2012).

"Edinburgh" is an approach to formation of a stable group with stable and clearly identified boundaries. The personal boundaries of the employees here are "erased", and therefore most of them feel "unity" with the group.

The principle of "unity in diversity" is fulfilled due to the balance between fragmentation and monotony. It cannot be distinguished in a separate approach, since an organization can use different strategies for managing diversity, depending on specific tasks and specifics of the situation. This principle reflects the basic tendency, the need to avoid unification, on the one hand, and fragmentation on the another, while considering organizational culture of the company in a whole (Leask, 2011). The second principle states that dilemma "fragmentation vs uniformity" is possible to be solved via integration. $\mathrm{K}$. Matoba emphasizes that in this case we are talking not about one side integration, but about process, which can be called more exactly as bilateral integration or mutual 
adaptation. In this case, the organization has no goal of monotony, but norms can be transmitted what provides the basis for the equal interaction of representatives of different cultures taking into account the potential of each (Briguglio, 2000).

The third principle - "cognitive diversity" - reflects the author's specifics of the concept. Referring to the research K. Matoba says that focusing on diversity by identifying differences in management leads to an emotional conflict. He suggests using the term "cognitive diversity", described in detail by S. Page, the use of which will not create conflicts, and, conversely, will lead to an increase in innovation, unlike the principle of "diversity of identities" (Matoba, 2003).

And, the final principle - "Communicative variety" - manifests itself in the idea that diversity in the organization can be carried out (paradoxically) with the temporary suspension of the differences associated with social identity. Unity (but not uniformity!) of organizations in this case is based on awareness of cognitive differences.

As an applied aspect of this principle realization K. Matoba distinguishes three main competencies that reflect its essence:

1) awareness of the social constructiveness of "cultural differences" and the ability to prevent their influence;

2) skills to identify and evaluate cognitive differences which are hidden behind differences of identities;

3) the ability to find and create a "functional interaction" between the cognitive differences of employees, which can contribute to the stability of self-regulating integrative organizational systems (Egege, \& Kutieleh, 2013).

It is quite clear that the first and second competencies relate to the skills of a specialist and/or linear manager, while the latter should be included in the description of the requirements to a representative of the management of a culturally diverse organization (Hunt, Chalmers, \& Macdonald, 2013).

In general, the "model of building a third culture" can be designated as an integrative constructivist approach to cultural differences in the organization. It correlates well with changes in the methodology of social psychology of the last decades, connected with the theory of social constructionism of K. Gergiev and theory of social identity by A. Tesfel.

\section{CONCLUSIONS}

Thus, the analysis of the trends of modern intercultural communication presented in the article suggests that enhancing intercultural competence of individuals and organizations is an important direction of applied ethnopsychology, which, in its turn, shows the importance of training specialists in this field.

Four main principles for the implementation of "the third culture" within the framework of corporate culture have been defined, namely: 1) unity in diversity; 2) integration; 3) cognitive variety; 4) communicative diversity.

As the result of the research three main competencies reflecting essence of crosscultural training have been determined. They are: 1) awareness of the social constructiveness of "cultural differences" and the ability to prevent their influence; 2) skills to identify and evaluate cognitive differences which are hidden behind differences of identities; 3) the ability to find and create a "functional interaction" between the cognitive differences of employees, which can contribute to the stability of self-regulating integrative organizational systems.

The prospect of our further research is to study the best practices of other countries in the area of cross-cultural training of future teachers for the creative use of their experience in the system of higher education of Ukraine. 


\section{REFERENCES}

1. Andreeva, G. M. (2009). Rezultaty stoletia (k voprosu o progresse v sotsialnoy psikhologii). Sotsialnaya psikhologia segodnya, 1 (3), 17-25.

2. Barker, M., Hibbins, R., \& Woods, P. (2012). Bringing forth the graduate as a global citizen: an exploratory study of master's level business students in Australia. In S. Slovic \& M. Blythman (Eds.) International students negotiating higher education: critical perspectives approach (pp. 142-154). London: Routledge.

3. Briguglio, C. (2000). Language and cultural issues for English as a second/ foreign language students in transnational education settings. Higher Education in Europe, 25 (3), 425-434.

4. Casmir, F. (1999). Foundations for the study of intercultural communication based on a third-culture building the model. International Journal of Intercultural Relations, $23(1), 67-73$.

5. Egege, S., \& Kutieleh, S. (2004). Critical thinking: teaching foreign notions to foreign students. International Education Journal, 4 (4), 75-85.

6. Hunt, L., Chalmers, D. \& Macdonald, R. (2013). Effective classroom teaching. In L. Hunt \& D. Chalmers (Eds.). University teaching in focus: a learning-centred approach (pp. 21-37). Camberwell, Victoria: ACER Press.

7. Matoba, K. (2003). Global dialogue - transformation through transcultural communication. Retrieved from http://www.idm-diversity.org/eng/infothek_matoba_glocaldialogue.html.

8. Leask, B. (2011). Assessment, learning, teaching and internationalisation: engaging for the future. Assessment, Teaching and Learning Journal, 11, 5-20.

9. Page, S. E. (2007). How the power of diversity creates better groups, firms, schools and societies. Princeton: Princeton University Press.

10. Pelled, L. H., Eisenhardt, K. M. \& Xin, K. R. (1999). Exploring the black box: An analysis of work group diversity conflict, and performance. Administrative Science Quarterly, 44, 123-128. 